simple names and expressions into collocations wholly meaningless in English. Thus the prince Vicitravirya (of wonderful valor) is said to be "of colorful virility" (p. xviii); and the common expression akrtatman (of weak or irresolute mind) appears in the translation as the alarming "those whose spirits are unmade." The latter is an example of the mistaken practice-inherited from the Victorian translators - of rendering atman, when it appears at the end of babuvribi compounds, as "soul" or "spirit" when it usually means "mind."

These examples, like those pertaining to the notes, have been chosen at random and offered by way of stbatipulakanyāya (the maxim of testing rice by a few grains), not to carp at or to denigrate van Buitenen's very genuine achievement but rather to focus on a major question regarding the method of work that has been adopted. There can be little doubt that the fairly large number of errors and misapprehensions that have crept into the work of so distinguished a Sanskritist as Professor van Buitenen must be attributed to the tremendous pressure of time that his plan to complete the entire work unaided must of necessity entail. There can be no other explanation for the brevity of the introduction and notes, and the general air of impatience with difficulties, that the translation exudes. It would be better if van Buitenen could modify his plans insofar as to consider the possibility of a more collaborative effort - at the very least a reading over of the text with a pandit, at the most the delegation of some portions to interested colleagues.

As it stands, the work is a sound, useful, and even a valuable contribution to indological scholarship. With proper care, and perhaps a slower pace, it could be far more so. I wish Professor van Buitenen every success in the continuing work on this monumental project.

One final word may be addressed to the publishers of this handsomely produced volume, with regard to the question of pricing. At the current rate, it is hard to see how the complete set could possibly cost less than $\$ 200$, even ignoring the possibility of further inflation. This is hardly in keeping with the author's intention of making the work as accessible as possible. The set will be a luxury to Western Sanskritists and an impossibility to their colleagues in India-all of whom deserve access to this important work. I suggest that the University of Chicago Press seriously look into the possibility of a collaboration with an Indian publisher whereby an edition could be produced in India from the same negatives. In this way, the set might be brought within the means of all the scholars for whose use it was intended.

University of California, Berkeley

ROBERT GOLDMAN

\title{
A Reply to Goldman
}

Possibly an even more thankless task than writing a book review is composing a rejoinder to it. But, in reviewing the first volume of my Mabäbbärata translation, Robert Goldman raises issues and passes judgments that deserve a reply, for he intends his criticisms to be constructive.

The theme of his review is his puzzlement that I am not a committee, that there is, perhaps, a touch of hubris in my going this translation alone. In 1967 I asked myself the question whether one man could master the entire $M B h$., and I recall writing my 
colleague Daniel H. H. Ingalls that in the end the translation could not be one man's work. He replied, "The only successful translation by committee ever completed is the King James Version, and they had divine inspiration."

So far, I have not felt the lack of a committee as urgently as Goldman does. There is such a thing as a scholar's work-style, over which, like taste, it is hard to quarrel. For my own part I find it both more congenial and more productive to work by myself, though hardly "in isolation," for there is no paucity of aids for the translator. I am not sure there is always strength in numbers: if five scholars know more or less the same, nothing but time is gained by their collaboration in translating different parts of one text; but if one knows more than the other four, something is in fact lost. A Sanskritist may be forgiven for wanting to read the $M B b$. from beginning to end. The ambition of writing down his translations may be somewhat overreaching, though the effort is not vitiated by that. The advantage of one translator throughout is that he can sustain an idiom and style which, if successful, holds the text together. Reading the entire text page after page, he will know more and more about his text. He will recognize differences - in tone, style, syntax, metrical treatment, and lexical usage-that would be less discernible to part-time translators. Indeed, the knowledge of many years of daily familiarity may allow him to understand rather than guess.

Goldman asserts that I am in a hurry, which I would not be if I had parceled out the work among a group of (say twenty) colleagues. There is no denying that somewhere in my lifetime I should like to see the task finished; I am not compulsive about the exact date. A steady daily regime of 30 to 50 slokas a day is not a frenzied dash to the finish, if one begins to know one's text. After finishing a volume I collate the entire text once more with the translation, on the assumption that I should know more after than before. Of course now I know much more than when Volume I went to press, but that is many thousands of slokas later. Also, every now and then I must have the satisfaction of seeing a volume appear and be read. A reader, and a reviewer, should keep in mind that right now I am still, for the first time, reading the $M B b$. Every volume is another step in work in progress. Only when complete can it be considered an oeuvre.

Therefore I will often not have an answer for the many questions that arise- not yet an answer or, I fear, never an answer-and so stay silent. The reader often knows as much as I do where we only have the text-I in the Sanskrit, he in my English. A good example: Goldman writes reproachfully that he was "particularly unhappy that the introduction gives so scanty a mention [viz. pp. $3 \mathrm{f}$.] of the famous snake sacrifice, omitting development of the peculiar connection of the epic-particularly the adiparvan-with the poorly understood cult of the nagas." The truth of the matter is that I simply knew no more than the text states and the reader reads. No amount of wordy speculation should have concealed that fact.

While Goldman likes the translation and is comparatively lavish in his praise, his strictures are formidable. He dislikes my "baron" for ksatriya-this has been an irritant for many others. I was guided here by Macdonell and Keith, Vedic Index of Names and Subjects, s.v. Kşatriya: "In the epic also the term Kşatriya ... would cover all the royal military vassals and feudal chiefs, expressing, in fact, pretty much the same as the barones of early English history." The choice probably was a mistake. Goldman also dislikes Law for dbarma, and condemns lawly (used once) and Unlaw (twice, I think), as "solecisms," though the OED records the former. Other points, such as occasional archaisms where I felt the context justified them, are mere matters of taste. On the other hand, I found "I thought I had it made" irresistible for krtbartbo'smiti cintayan 
(quoted in the Notes to alert the reader); I must warn that, in Volume II, I have even permitted myself: "Do your thing."

Goldman has detected also "a surprisingly large number of inaccuracies, one of which may be found on nearly every page." To this I must take exception. This means that in Volume I there are over 400 "inaccuracies" of "undertranslation, overtranslation, and simple mistranslation." Declaring that in this journal, whose readership includes many for whom my translation is intended, is imputing my trustworthiness as a translator. Goldman has selected ten:

I. There is no punning in bbunkta. The root bbuj is not used in the epic for "enjoying sexually." The point of the Sanskrit usage is that Kuntī's reply is "colorless," an automatic maternal response, which makes the awesome consequences of her words even more starkly dramatic.

2. "usages": Webster notes the meaning "the way in which words and phrases are actually used." I intended neither "poetic convention" nor "literary usage."

3. Abbiseka does not have the sense of "final ritual bath" in the epic, but "the ritual sprinkling of the head." Goldman's English translation would represent krtävabrtha or simply krtasnana. Thus the note was necessary.

4. Grdbini is much stronger than "eager": root grdh. "to be greedy, to the point of cheating" ; compare grdbra "vulture."

5. Häbäkrtam can perfectly well be taken as a passive construction with dhanusä. It can also be taken with rajjäam mandalam. The choice is a matter of judgment, not of accuracy.

6. sütaputrena: I cannot see any possibility of confusion, since Karna occurs in the context. Also, by now we are 120 stanzas distant from the bard Ugraśravas.

7. gäthä: "verse" is correct, "legend, story" is incorrect; the verse is an anuvamía śloka (chronicle verse) on Vyuşitāśva.

8. hälisäă: I stand corrected.

9. "Of colorful virility" is a very possible translation of Vicitravĩrya's name, as he seemed to have died of sexual excess. Moreover, this translation does not occur in the body of the text.

Io. I am not prone to the "Victorian practice" of translating attman as "soul" or "spirit" at all times. I dispute that it normally means "mind" (note the difference between mahätman and mabämanas). To my ears, "spirit" is vaguer than "soul," and corresponds better to the often equally vague atman.

In sum it would seem that these ten "inaccuracies," nine of which are not, are not quice the representative sample from which another 400 can be postulated.

In the Notes, Goldman finds more "inaccuracies," the first one in the very first note on the introductory verse of the $M B b$. He questions my interpretation of jaya as "victory." Let me make the following points: I. Jaya does occur in the $M B h$. as the name of the epic; 2. Nara and Nārāyaña invoked in the verse are repeatedly identified with (earlier incarnations of) Arjuna and $\mathrm{K}_{\text {rsna }}$, two principal heroes of the $M B b$. 3. The verse traditionally introduces the $M B b$. Given these three facts, is it not likely that jaya here be understood as "Triumph" as a name of the epic? Even supposing that the verse comes from elsewhere (and Sukthankar fails to convince me), its inclusion here would be due to the fact that it was believed that jaya referred to the epic, and one might thus interpret the sloka accordingly. That the verse also introduces a number of Purānas is hardly surprising, since the same author Vyāsa is also the "author" of the eighteen Puranas. My interpretation is likelier than Goldman's tame "after honoring Nara, 
Nārāyaṇa and Sarasvatī he should say 'Jaya!'," which should have been jayety udirayet in Sanskrit, and so is inaccurate.

Another example of a "poorly thought-out note" is the one where I confess uncertainty about the meaning of śvacarite märge. I happen to have given this note a little more thought than Goldman, and still I remain uncertain. While Goldman chides me for not consulting any Indian pandit, who would have "cleared up in a moment" what I find puzzling, I did in fact consult Dr. V. Raghavan on this passage when he visited me in Delhi in 1968. He too found it puzzling. Manu compares serving a king with a dog's life, which is irrelevant here. The "way of the dogs" is mentioned twice, the second immediately after the first; this is always suspect, for the second looks like a gloss of the first. Goldman is no help. He takes for granted that he knows the exact meaning of the idiom here ("a not uncommon idiom for the life of servitude") and therefore does not understand my hesitations ("what he finds so difficult about the passage"), yet concludes: "admittedly the whole passage [i.e., sloka 20, with the glossing sloka 21] is poorly adapted to the situation of Pāndu." This admission was my own starting point, and made me conclude that I did not understand the precise meaning here of the idiom.

This reply does, I think, deal fairly and dispassionately with matters of substance that Goldman cites. There are others that cannot be responded to, because they are matters of opinion. Goldman feels I should have been more elaborate in the Introduction, while I felt I was not ready to pronounce on many matters when I had read only one-tenth of the $M B b$. The limits one person sets for himself are not necessarily those of another. Let me repeat what I said in my Introduction: we do not know enough of the $M B b$; and this we includes most Sanskritists I know. The text has not, so far, been usefully presented; therefore to do so was my first and overriding concern. Now 2,000 people have the book on their shelves, and can study and help us explain it.

So, a final response to Goldman's Parthian shot, aimed not at me but at my publisher, the University of Chicago Press. The book is not overpriced. It is underpriced, due to a $\$ 7,500$ subsidy the author raised; without that, the fair market price would have been $\$ 22.50$. This book could not have been produced for 150 rupees in present-day India in so fair a form. Could there not have been some praise for the real risk the publisher undertook with this volume-as well as the next ones - in a depressed publishing market where so many of our colleagues find it dispiritingly hard to publish the fruits of their labors?

The University of Chicago

J. A. B. van BuITENEN 